\title{
Preclinical Neurochemical and Electrophysiological Profile of 1192U90, A Potential Antipsychotic
}

Stacey A. Jones-Humble, M.S., Michael J. Durcan, Ph.D., Donald Lyerly, B.A., Ronald M. Norton, M.S., Flora L. M. Tang, M.S., Anne V. Russell, B.S., Michael J. Watson, M.S., Peter J. Gengo, Ph.D., Philip F. Morgan, Ph.D., Ching M. Wang, Ph.D., Barrett R. Cooper, Ph.D., and Richard F. Cox, Ph.D.

11192490 a'as submitted to receptor binding and monoamine uptake assays. It bound potently at serotonin $5-H T_{2}$, dopaminergic $D_{2}$, serotonin $5-H T_{1 A}$, and adrenergic $\alpha_{1}$ and $\alpha_{2}$ receptors. It also bound to dopaminergic $D_{1}$, serotonin $5-H T_{3}$, serotonin $5-H T_{4}$, and sigma sites, albeit with lower affinity. It was essentially inactive at 22 other sites, including those for cholinergic $M_{1}$ and $M_{2}$. It areakly inhibited uptake of ${ }^{3} H$-norepinephrine, ${ }^{3} \mathrm{H}$-serotonin and ${ }^{3} \mathrm{H}$-dopamine. Acute toses of $1192490(5$ and $20 \mathrm{mg} / \mathrm{kg}$ P.O.) increased allole-brain levels of dopamine metabolites but did not affect levels of norepinephrine, dopamine, and serotonin.

Subcutaneons injection of $1192490(0.8 \mathrm{mg} / \mathrm{kg} / \mathrm{day})$ and clozapine $(20 \mathrm{mig} / \mathrm{kg} /$ day) for 28 days preferentially decreased the number of spontaneonsly active dopamine cells in the oentral tegmental area (VTA) but not the

KEY WORDS: Neurotransmitter; Receptor; Uptake; HPLC; Dopamine turnower; Atypical antipsychotic; Single-unit recording; Dopamine; Serotonin; Substantia nigra; Ventral tegmental area; Dorsal raphe nucleus

There is substantial need for an agent that can manage the symptoms of schizophrenia. Although the typical antipsychotics such as chlorpromazine and haloperidol

From the [harmacology Division, Burroughs Wellcome Co. Research Triangle Park, NC.

Address correspondence to: Stacey A. Jones-Humble, Molecular Pharmacology, Glaxo Wellcome, Research Triangle Park, NC 27709.

Received June 30, 1995; revised December 21, 1995; accepted January 1,1996 substantia nigra (SN) of rats, as measured by population sampling. This outcone is characteristics of atypical antipsychotics like clozapine. Acute injections of 1192490 reversed the rate-inhibiting effects of microiontophoretically applied dopamine and intravenously injected apomorphine and d-amphetamine on dopamine cell firing. Intravenous injection or iontophoretic application of 1192490 or the 5-HT 1 agonist ( \pm )8-OH-DPAT inhibited the firing rates of dorsal raphe nucleus (DRN) neurons in rats, and the effects of both compounds were blocked by iontophoretically applied $S(-)$ propranolol, a 5-HT 1 antagonist. The results suggest that 1192490 is a preferential dopamine $\mathrm{D}_{2}$ antagonist as well as a $5-H T_{1}$ agonist that may prove to be an atypical antipsychotic. [Neuropsychopharmacology $15: 217-230,1996]$

were a major advance, they were effective in only a portion of the patient population and were ineffective for the negative symptoms of schizophrenia (Lieberman 1993). The side effect profile of these drugs was poor; severe extrapyramidal side effects, including dystonia, Parkinsonism, akathisia, and tardive dyskinesia were common (Tarsy 1983). In some instances, tardive dyskinesia remained even after discontinuation of drug therapy (Tarsy 1983).

Clozapine is an atypical antipsychotic in that it is effective against both positive and negative symptoms (Kane et al. 1988; Meltzer et al. 1989; Lieberman 1993) and dose not cause Parkinsonism, dystonia, or tardive dyskinesia (Gerlach et al., 1974; Shopsin et al. 1979; 
Figure 1. 1192490, 2-amino-N-(4(4-(1,2-benzisothiazol-3-yl)-1-piperazinyl)butyl)benzamide.

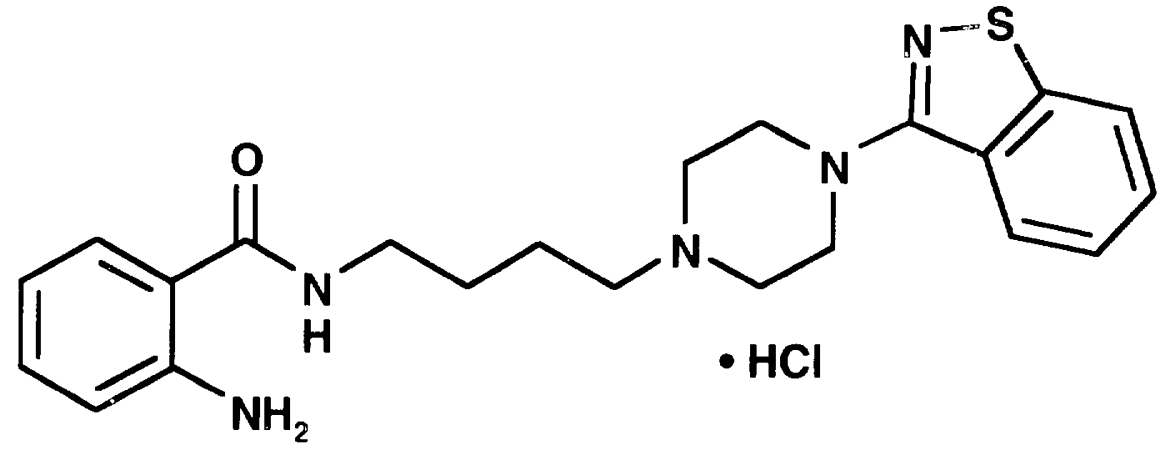

Claghorn et al. 1987; Casey 1989). Howerer, it has other side effects, including seizures, hypotension, sedation, and sialorrhea (Shopsin et al., 1979; Meltzer 1992). These are likely to be due to the fact that clozapine has actions at a variety of neurotransmitter receptors in brain, including histamine ${ }_{1}$ and muscarinic receptors (Coward 1992). The major limiting side effect of clozapine is its association with agranulocytosis (IdänpäänHeikkilä et al. 1975; Griffith and Saameli 1975; Lieberman et al. 1988). There are no drugs on the market that address both the positive and negative symptoms of schizophrenia without the risk of severe, debilitating side effects.

1192 40 is active in animal models that predict clinical antipsychotic efficacy (Figure 1). Differing from the typical antipsychotic medications, 1192U90 is similar to the atypical agent clozapine in that it does not block apomorphine-induced stereotypy in rats, nor does it cause catalepsy, which indicates that it may have a reduced side effect liability (Coward 1992; Rigdon et al. 1996). 1192U90 blocks conditioned aroidance responding in rats (Rigdon et al. 1996) and has dopamine antagonist effects on animal behavior. It blocks apomorphineinduced climbing in mice and apomorphine-induced rotation in rats with unilateral lesions of the nigrostriatal system (Rigdon et al. 1996). In other behavioral tests, $1192 \mathrm{U} 90$ acts like a $5-\mathrm{HT}_{2}$ antagonist in that it prevents 5 -HTP-induced head shakes in rats (Rigdon et al. 1996). Like 5-HT 1 a agonists, it also increases punished responding in pigeons and cork gnawing in rats (Rigdon et al. 1996).

The purpose of this report is to characterize and describe the neurochemical and electrophysiological attributes of 1192U90.

\section{METHODS}

\section{Neurochemistry}

Receptor Binding. Radioligand receptor binding assays were adapted from previously published methods (Table 1). Radioligands were obtained from DuPont NEN (Boston, MA), Amersham (Arlington Heights, IL) or
Moravek Biochemicals (Brea, CA). Standards and ligands used to determine non-specific binding were obtained from Research Biochemicals International (Natick, MA) and Sigma Chemical Co. (St. Louis, MO). $K_{i}$ values were determined using the Cheng-Prusoff equation (Cheng and Prusoff 1973).

Uptake. The effect of 1192 U90 on the net uptake of norepinephrine (NE), dopamine (DA); and serotonin (5-HT) was measured essentially as described previously (Ferris and Tang 1979; Slotkin et al. 1986). The hypothalamus (5-HT and NE uptake) or striatum (DA uptake) from rats were homogenized in 18 volumes of Sucrose-Tris buffer (0.3 M sucrose, $25 \mathrm{mM}$ Tris, $\mathrm{pH} 7.4)$ by a Potter-Elvenhjem homogenizer with a Teflon pestle. The homogenate was centrifuged at $1,000 \times \mathrm{g}$ for 10 minutes at $4^{\circ} \mathrm{C}$. The supernatant was removed and used in the assay. 1192U90 was pre-incubated with the tissue in modified Krebs-Henseleit buffer $(118 \mathrm{mM} \mathrm{NaCl}, 5$ $\mathrm{mM} \mathrm{KCl}, 25 \mathrm{mM} \mathrm{NaHCO}, 1.2 \mathrm{nM} \mathrm{NaH} \mathrm{PO}_{4}, 1.2 \mathrm{mM}$ $\mathrm{MgSO}_{4}, 11 \mathrm{mM}$ glucose, $2.5 \mathrm{mM} \mathrm{CaCl}_{2}, \mathrm{pH} 7.4$ ) at $37^{\circ} \mathrm{C}$ for 5 minutes. ${ }^{3} \mathrm{H}$-Neurotransmitter was added and allowed to incubate for an additional 5 minutes. ${ }^{3} \mathrm{H}-\mathrm{Neu}$ rotransmitter that had been transported into the synaptosomes was separated from ${ }^{3} \mathrm{H}$-neurotransmitter remaining outside by rapid filtration over GF/B filters followed by three rapid washes with ice-cold modified Krebs-Henseleit buffer. Filters were placed in ReadySafe scintillation cocktail and counted on a Packard TriCarb Scintillation Counter. Vonspecific uptake was defined as uptake at $0^{\circ} \mathrm{C}$.

Biogenic Amine Levels. Adult male Wistar rats $(n=7$ per group) were orally dosed with haloperidol (1 mg/ $\mathrm{kg}), 1192 \mathrm{~L} 90\left(5\right.$ or $20 \mathrm{mg} / \mathrm{kg}$, representing the $\mathrm{ED}_{50}$ and four times the $E D_{50}$ for antipsychotic efficacy in behavioral tests, Rigdon et al. 1996), or $0.5 \%$ methylcellulose vehicle. One hour later they were sacrificed by decapitation, and whole brains were immediately removed to dry ice. The tissues were stored at $-80^{\circ} \mathrm{C}$ until analysis ( $\leqslant 1$ week).

Biogenic amines were extracted by homogenizing 
Table 1. Receptor Binding Methods

\begin{tabular}{|c|c|c|c|c|c|}
\hline Receptor & ${ }^{3} \mathrm{H}$-Ligand (nM) & Species & Tissue & $\begin{array}{l}\text { Ligand Used to } \\
\text { Determine Non- } \\
\text { specific Binding }\end{array}$ & Reference \\
\hline Dopaminergic $\mathrm{D}_{1}$ & SCH-23390 (0.2) & Rat & Striatum & SCH-23390 & Billard et al.,1984 \\
\hline Dopaminergic $D_{2} / D_{3}$ & raclopride (1) & Rat & Striatum & Sulpiride & Dewar et al., 1989 \\
\hline Serotonergic $5-\mathrm{HT}_{1 \mathrm{~A}}$ & 8-OH-DPAT (0.2) & Rat & Hippocampus & Serotonin & Peroutka, 1986 \\
\hline Serotonergic $5-\mathrm{HT}_{2}$ & Ketanserin $(0.5)$ & Rat & Frontal cortex & Ketanserin & Leysen et al., 1982 \\
\hline Serotonergic $5-\mathrm{HT}_{3}$ & BRL $4369+(0.5)$ & Rat & Cerebral cortex & N-Methylquipazine & $\begin{array}{l}\text { Nelson and } \\
\text { Thomas, } 1989\end{array}$ \\
\hline Serotonergic $5-\mathrm{HT}_{4}$ & GR $113808(0.1)$ & Rat & Striatum & Serotonin & Grossman et al., 1993 \\
\hline Adrenergic alphal & WB-4101 (0.2) & Rat & Whole brain & Vorepinephrine & Greenberg et al., 1976 \\
\hline Adrenergic alphaz & Yohimbine (1) & Rat & Cerebral cortex & Norepinephrine & Rouot et al., 1982 \\
\hline Adrenergic betal & 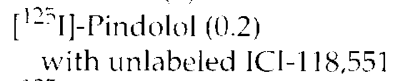 & Rat & Cerebral cortex & Isoproterenol & $\begin{array}{l}\text { Kalaria et al., 1989; } \\
\quad \text { Minneman et al., } 1979\end{array}$ \\
\hline Adrenergic beta2 & $\begin{array}{l}{\left[{ }^{125} 1\right]-\text { Pindolol }(0.2)} \\
\text { with unlabeled ICI-89, } 406\end{array}$ & Rat & Cerebral cortex & Isoproterenol & $\begin{array}{l}\text { Kalaria et al., 1989; } \\
\quad \text { Minneman et al., } 1979\end{array}$ \\
\hline Cholenergic $\mathrm{M}_{1}$ & Pirenzepine (1) & Rat & Forebrain & Atropine & Watson et al., 1983 \\
\hline Cholinergic $\mathrm{M}_{2}$ & QNB $(0.05)$ & Rat & Heart & Atropine & Watson et al., 1983 \\
\hline Cannabinoid & WIN 55,212-2(1) & Rat & Cerebellum & WIN $55,212-2$ & D'Ambra et al., 1992 \\
\hline Sigma & SKF $100+7(3)$ & Guinea pig & Whole brain & $\begin{array}{l}\text { Ethylketo- } \\
\text { cyclazocine }\end{array}$ & Tam, 1983 \\
\hline Neurotensin & Veurotensin (2) & Rat & Forebrain & Neurotensin & Goedert et al., 1984 \\
\hline $\begin{array}{l}\text { Neurokinin }_{1} \\
\quad \text { (Substance P) }\end{array}$ & Substance $P(1 . t)$ & Rat & $\begin{array}{l}\text { Submaxillary } \\
\text { glands }\end{array}$ & Substance P & $\begin{array}{l}\text { Bahouth and } \\
\text { Musacchio, } 1985\end{array}$ \\
\hline Neurokinin, $\left(N K_{\Lambda}\right)$ & $\left.1^{12 \overline{7}} \mathrm{I}\right]-$ Neurokinin $\mathrm{A}(0.1)$ & Bovine & Duodenum & Neurokinin A & Burcher et al., 1986 \\
\hline Neurokinin $3\left(\mathrm{NK}_{\mathrm{B}}\right)$ & Eledoisin & Rat & Cerebral cortex & Eledoisin & $\begin{array}{l}\text { Mussap and } \\
\text { Burcher, } 1990\end{array}$ \\
\hline Benzodiazepine & diazepam (1.5) & Rat & Forebrain & Diazepam & $\begin{array}{l}\text { Marangos and } \\
\text { Martino, } 1981\end{array}$ \\
\hline Leukotriene $D_{+}$ & Le'ukotriene $\mathrm{D}_{4}(0.4)$ & Guinea pig & Lung & Leukotriene $\mathrm{D}_{4}$ & $\begin{array}{l}\text { Cheng and } \\
\text { Townley, } 1984\end{array}$ \\
\hline Cholecystokinins & $\mathrm{CCK}_{8}(0.2)$ & Mouse & Cerebral cortex & CCK4 & Saito et al., 1981 \\
\hline $\begin{array}{l}\text { Platelet activating } \\
\text { factor }\end{array}$ & $\operatorname{PAF}(0.2)$ & Rabbit & Platelet & PAF & Hwang et al., 1986 \\
\hline Angiotensin II & Angiotensin II (1) & Rat & Liver & Angiotensin 11 & Lynch et al., 1985 \\
\hline $\begin{array}{l}\mathrm{Ca}^{++} \text {channel } \\
\text { (dihydropyridine) }\end{array}$ & Nitrendipine $(0.2)$ & Rat & Cerebral cortex & Nifedipine & Gould et al., 1982 \\
\hline $\begin{array}{l}\mathrm{Ca}^{+} \text {channel } \\
\text { (phenylalkylamine) }\end{array}$ & Verapamil (1) & Rat & Heart & Verapamil & Reynolds et al., 1986 \\
\hline $\begin{array}{l}\mathrm{Ca}^{-+} \text {channel } \\
\text { (Ryanodine) }\end{array}$ & Ryanodine (3.3) & Dog & Heart & Ryanodine & Rardon et al., 1990 \\
\hline $\begin{array}{l}\text { ATP-dependent } \\
\mathrm{K}^{+} \text {channel }\end{array}$ & Glibenclamide (0.1) & Rat & Whole brain & Glibenclamide & $\begin{array}{l}\text { Gopalakrishnan } \\
\text { et al., } 1991\end{array}$ \\
\hline $\begin{array}{l}\text { ATP-dependent } \\
\mathrm{K}^{+} \text {channel }\end{array}$ & Glibenclamide (0.06) & Rat & Heart & Glibenclamide & $\begin{array}{l}\text { Gopalakrishnan } \\
\text { et al., } 1991\end{array}$ \\
\hline GABA Cl channel & [.̄ंs]-TBPS (1) & Rat & Cerebral cortex & Picrotoxinin & $\begin{array}{l}\text { Eshleman and } \\
\text { Murray, } 1990\end{array}$ \\
\hline Endothelin A & 125I-ET-1 (0.03) & Rat & Cerebellum & ET-1 & $\begin{array}{l}\text { Waggoner } \\
\text { et al., } 1992\end{array}$ \\
\hline Endothelin B & 125I-ET-1(0.03) & Rat & Cerebral cortex & ET-1 & $\begin{array}{l}\text { Waggoner } \\
\text { et al., } 1992\end{array}$ \\
\hline $\begin{array}{l}\text { Adenosine } \\
\text { transporter }\end{array}$ & Dipyridamole (t) & Guinea pig & Whole brain & Dipyridamole & $\begin{array}{l}\text { Marangos and } \\
\text { Deckert, } 1987\end{array}$ \\
\hline
\end{tabular}

each tissue sample of a known weight in $0.1 \mathrm{M}$ cysteine in $5 \%$ trichloroacetic acid along with a known amount of 3,4-dihydroxybenzylamine (DHBA) as an internal standard. The homogenate was centrifuged at 48,000 $\times$ $\mathrm{g}$ for 20 minutes at $5^{\circ} \mathrm{C}$. The supernatant was removed and centrifuged again to ensure removal of all particulates. A $10-\mu l$ aliquot of the resulting supernatant was analyzed by HPLC coupled to an electrochemical detector. Samples were kept at 0 to $5^{\circ} \mathrm{C}$ throughout preparation. 
Neurotransmitters and their metabolites were separated on a Chromanetics Spherisorb ODS 2 stationary phase $(4.5 \times 150 \mathrm{~mm}, 5-\mu \mathrm{m}$ particles $)$ at $35^{\circ} \mathrm{C}$. Analytes were eluted at $1.0 \mathrm{ml} /$ minute with a mobile phase consisting of $60 \mathrm{mM} \mathrm{NaH} \mathrm{PO}_{4}, 31 \mathrm{mM}$ citric acid, $0.27 \mathrm{mM}$ EDTA, 1.0 mM 1-octane sulfonic acid (sodium salt), and $16 \%$ methanol in HPLC grade water. The methanol was added after the $\mathrm{pH}$ of the aqueous component was adjusted to 3.0. Each sample was introduced to the system via a refrigerated autoinjector kept at $5^{\circ} \mathrm{C}$. The analytes were monitored by amperometric electrochemical detection at a potential of $800 \mathrm{mV}$. The resulting data were collected on a Perkin Elmer Model 1020 Electronic Integrator. Brain amine levels were calculated based on the recovery of the internal standard. The entire system was recalibrated after every five samples.

\section{Electrophysiology}

General Methods. 1192 U90 was synthesized by Dr. Mark Norman at Burroughs Wellcome Co. ( \pm )8-hydroxydipropylaminotertralin (8-OH-DPAT), $\mathrm{S}(-)$-propranolol hydrochloride, and 3-hydroxytyramine (dopamine) were obtained from Research Biochemicals International (Natick, MA). Chloral hydrate and apomorphine were obtained from Sigma Chemical Co. (St. Louis, MO). d-Amphetamine was a gift from Smith Kline \& French (Philadelphia, PA). Haloperidol was a gift from McNeil Pharmaceutical (Raritan, NJ). Clozapine was gift from Sandoz Pharmaceuticals (East Hanover, $\mathrm{NJ}$ ).

Male CD rats weighing 200 to $300 \mathrm{~g}$ (Charles River Laboratories, Raleigh, NC) served as subjects. For single-unit and microiontophoresis experiments, they were anesthetized with chloral hydrate $400 \mathrm{mg} / \mathrm{kg}$ IP and secured in a stereotaxic apparatus (David Kopf Instruments, Tajunga, CA). A lateral tail vein was cannulated for drug injections. Additional chloral hydrate was given IV as needed to maintain anesthesia. Body temperature was maintained at 36 to $38^{\circ} \mathrm{C}$ with a heating pad. The skull was exposed and a small hole was drilled overlying the area of the substantia nigra (SN), ventral tegmental area (VTA), or dorsal raphe nucleus (DRN). Single- or multi-barrel electrodes were prepared and were lowered through the hole in the skull to the appropriate brain region by an electric microdrive (Burleigh Instruments, Fishers, NY).

Electrical signals of single-unit discharges were passed through a high-input impedance amplifier and filtered through a window discriminator with bandpass settings at $400 \mathrm{~Hz}$ and $2 \mathrm{kHz}$ (Fintronic WDR-420, Fintronic Inc., Orange, CT). Discriminator output was displayed on an oscilloscope and amplified through an audio monitor. Neuronal activity was counted, summed over 10-sec bins, plotted by a Gould recorder, and printed by a Datel printer. During microiontophoresis experiments, current balancing, holding currents, and ejection currents were controlled by a Fintronics E-104 microiontophoresis unit.

After the last electrode penetration in any experiment, $25 \mathrm{~mA}$ of negative current was delivered through the electrode tip to deposit dye at the site of recording. Rats were euthanized under chloral hydrate anesthesia by injection of an air embolus. Brains were removed and fixed in $10 \%$ phosphate buffered formalin. Visualization of dye spots and electrode tracks on brain slices confirmed proper electrode placement.

\section{Dopamine Neurons: Antagonism of the Inhibitory Effects} of Apomorphine and d-Amphetamine. Dopamine neurons were located within the sterotaxic coordinates 2 to $2.4 \mathrm{~mm}$ lateral (L) from the midline suture, 2.8 to 3.4 $\mathrm{mm}$ anterior (A) from lambda, and $6.0-8.5 \mathrm{~mm}$ ventral (V) from the surface of the brain for SN, or 0.4 to $1.0 \mathrm{~mm}$ $\mathrm{L}, 3.0$ to $3.4 \mathrm{~mm} \mathrm{~A}$, and 6.0 to $8.5 \mathrm{~mm} \mathrm{~V}$ for VTA. Dopamine neurons in each brain region were identified by standard electrophysiological criteria: slow firing rate (1-10 spikes/sec) with regular or bursting firing patterns, of over 2-sec duration with notched bi- or triphasic wave form (Aghajanian and Bunney 1977; White and Wang 1984; Cox et al. 1988).

In experiments with IV drug injection, single-barrel glass electrodes were used to record neuronal activity. After a neuron identified as a dopamine cell was encountered, stable baseline firing was recorded for 3 to 5 minutes. Doses of apomorphine $(20-50 \mu \mathrm{g} / \mathrm{kg}$ cumulative) or $d$-amphetamine $(0.5-1.5 \mathrm{mg} / \mathrm{kg}$ cumulative) were injected every 1 or 2 minutes to produce partial but nearly complete inhibition of firing rate. Doses of 1192U90 $(6.25-200 \mu \mathrm{g} / \mathrm{kg}$ cumulative $)$ or haloperidol (5-100 $\mu \mathrm{g} / \mathrm{kg}$ cumulative) were subsequently injected. Responses to the agonists and 1192U90 or haloperidol on firing rates were determined by averaging the final 60 seconds of each dose interval and expressing it as a percentage of the baseline. Responses were then averaged across doses and expressed as a mean \pm standard error of the mean (SEM) for each group of rats.

In iontophoresis experiments, the central barrel of a five-barrel glass microelectrode (Activational Systems, Inc., Warren, MI) was filled with $2 \mathrm{M} \mathrm{NaCl}$ containing $1 \%$ Pontamine sky blue dye (impedance 3-12 M 2 ) and was used for recording neuronal firing. One side barrel was filled with $0.2 \mathrm{M} \mathrm{NaCl}$ and used for current balancing (in vitro impedance $\sim 20 \mathrm{M} \Omega$ ). One side barrel contained dopamine $(0.1 \mathrm{M}, \mathrm{pH} 4)$ that was applied to inhibit dopamine cell firing. Another barrel contained $1192 \mathrm{~L} 90(1 \mathrm{mM}, \mathrm{pH} 3)$. The in vitro impedance of the drug-containing side barrels was between 60 and 110 $M \Omega$ After the baseline firing rate of a cell was recorded, dopamine was first applied alone (10-40 nA) for $60 \mathrm{sec}-$ onds and the response was recorded. After the firing rate had returned to baseline values, 1192U90 (10-20 
Table 2. Receptor Binding Results: $K_{i}$ in $\mathrm{nM}$ (or $\%$ inhibition at $10 \mu \mathrm{M}$ )

\begin{tabular}{|c|c|c|c|}
\hline Receptor & 1192 U90 & Risperidone & Clozapine \\
\hline Dopaminergic $\mathrm{D}_{1}$ & 140 & 320 & 84 \\
\hline Dopaminergic $\mathrm{D}_{2} / \mathrm{D}_{3}$ & 22 & 16 & 200 \\
\hline Serotonergic $5-\mathrm{HT}_{1 \mathrm{~A}}$ & $2.5^{i l}$ & $290^{a}$ & $1300^{\prime \prime}$ \\
\hline Serotonergic $5-\mathrm{HT}_{2}$ & $1.5^{b}$ & $0.7^{?}$ & $13^{b}$ \\
\hline Serotonergic $5-\mathrm{HT}_{3}$ & 1300 & & \\
\hline Serotonergic $5-\mathrm{HT}_{4}$ & 2400 & 480 & $>10000$ \\
\hline Adrenergic alpha ${ }_{1}$ & 0.26 & 3.3 & 41 \\
\hline Adrenergic alphaz & $11^{\circ}$ & $11^{\circ}$ & $82^{\circ}$ \\
\hline Adrenergic beta 1 & [12] & & \\
\hline Adrenergic beta 2 & [25] & & \\
\hline Sigma & 470 & & \\
\hline Cholinergic $\mathrm{M}_{1}$ & [51] & & $40^{d}$ \\
\hline Cholinergic $\mathrm{M}_{2}$ & [51] & & $4^{d t}$ \\
\hline
\end{tabular}

" $K_{i}$ calculated by using $K_{i}$ from Giozlan et al. 1983.

" $K_{i}$ calculated by using $K_{i}$ from Leysen et al. 1982.

' $K_{i}$ calculated by using $K_{i}$ from Rouot et al. 1982.

"ic $\mathrm{C}_{\overline{5} 1}$.

nA) was applied for 180 seconds and a pulse of dopamine was applied during seconds 60 to 120 (i.e., during the second minute) of the application. The effects of dopamine alone and with 1192U90 were determined by expressing the mean firing rate during iontophoretic ejection as a percentage of the baseline rate. Responses were averaged across ejection currents and expressed as a mean \pm SEM.

Dopamine Neurons: Population Sampling after Acute and Chronic Administration of 1192490 and Clozapine. $1192 \mathrm{U} 90(0.8 \mathrm{mg} / \mathrm{kg} / \mathrm{day})$ or clozapine $(20 \mathrm{mg} /$ $\mathrm{kg} /$ day) was injected SC either acutely ( 2 hours before the first electrode penetration) or chronically for 28 days with the last dose given 2 hours before the first electrode penetration. The dose of 1192L90 was chosen because it is the $\mathrm{ED}_{84}$ by the subcutaneous route in the rat conditioned avoidance test (Rigdon et al. 1996). The dose of clozapine was chosen from the literature to allow comparison with published values (White and Wang 1983b). The experimenter conducting population sampling studies was not blind to treatment conditions.

A single-barrel glass electrode was slowly advanced
Table 3. Receptor Binding Results: $\mathrm{IC}_{50}$ (or $\%$ inhibition at $10 \mu \mathrm{M}$ )

\begin{tabular}{|c|c|}
\hline Receptor & 1192U90 \\
\hline Adenosine transporter & [14] \\
\hline Angiotensin II & [3] \\
\hline ATP dependent & [0] \\
\hline \multicolumn{2}{|l|}{$\mathrm{K}^{+}$channel (brain) } \\
\hline ATP dependent & {$[0]$} \\
\hline \multicolumn{2}{|l|}{$\mathrm{K}^{+}$channel (heart) } \\
\hline Benzodiazepine & {$[2]$} \\
\hline $\mathrm{Ca}^{++}$channel (phenylalkylamine) & 6800 \\
\hline $\mathrm{Ca}^{++}$channel (dihydropyridine) & {$[18]$} \\
\hline $\mathrm{Ca}^{++}$release channel (Ryanodine) & [7] \\
\hline Cannabinoid & [10] \\
\hline Cholecystokinin 8 & [3] \\
\hline Endothelin A & {$[3]$} \\
\hline Endothelin B & {$[6]$} \\
\hline $\mathrm{GABA} \mathrm{CI}^{--}$channel & [4] \\
\hline Leukotriene $\mathrm{D}_{4}$ & [2] \\
\hline Veurotensin & [0] \\
\hline Neurokinin $_{1}$ & [2] \\
\hline Neurokinin $_{2}$ & {$[36]$} \\
\hline Neurokinin $_{3}$ & {$[8]$} \\
\hline Platelet activating factor & [29] \\
\hline
\end{tabular}

(5-10 microns/sec) into a predetermined stereotaxic array over the SN or VTA. Penetrations were repeated for 12 tracks at identical stereotaxic coordinates in each rat. Each penetration was separated by $0.2 \mathrm{~mm}$, and the order of first penetration (SN or VTA) was reversed for each successive rat.

Spontaneously active dopamine neurons were counted, and the firing of each neuron was recorded for several minutes. Results are reported as the number of spontaneously active cells/track/rat and the mean spontaneous firing rate (each expressed as a percentage of the corresponding value from a vehicle control group).

Serotonin Neurons: Effects of Acute 1192490 on Dorsal Raphe Unit Activity. Neurons of the DRN were located within the stereotaxic boundaries $0.0-0.2 \mathrm{~mm}(\mathrm{~L}), 0.3-$ $0.7 \mathrm{~mm}$ (A), and 5.5-6.5 mm (V). Serotonin neurons were identified by elecrophysiological characteristics: slow firing rates $(0.2-3$ spikes $/ \mathrm{sec})$ and wide positive-

Table 4. Effects of Haloperidol or $1192 \mathrm{U} 90$ on the Concentration of Rat Brain Biogenic Amines Biogenic Amine Levels (pmol/mg of wet weight)

\begin{tabular}{lllllll}
\hline \multicolumn{1}{c}{ Treatment Group } & \multicolumn{1}{c}{ NE } & \multicolumn{1}{c}{ DA } & DOPAC & \multicolumn{1}{c}{ HVA } & 5-H IAA & 5-HT \\
\hline Control & 6.02100 & $8.06(100)$ & $0.82(100)$ & $1.3(100)$ & $1.8(100)$ & $3.6(100)$ \\
Haloperidol $(1 \mathrm{mg} / \mathrm{kg}$ PO) & $5.6(93)$ & $7.7(96)$ & $1.1^{b}(134)$ & $1.5^{b}(115)$ & $1.9(106)$ & $3.6(100)$ \\
$1192 \mathrm{U} 90(5 \mathrm{mg} / \mathrm{kg} \mathrm{PO})$ & $6.6(110)$ & $8.2(102)$ & $1.1^{b}(134)$ & $1.5^{b}(115)$ & $2.1^{b}(117)$ & $3.4(94)$ \\
$1192 \mathrm{U} 90(20 \mathrm{mg} / \mathrm{kg} \mathrm{PO})$ & $5.9(98)$ & $8.1(100)$ & $1.5^{b}(183)$ & $1.8^{b}(138)$ & $2.3^{b}(128)$ & $3.4(94)$ \\
\hline
\end{tabular}

"Vahues in parenthesis represent" of control

"Significantly different from control $(p<0.05)$ by two-tailed $t$ test 
Figure 2. Reversal by 1192 U90 of d-amphetamine-induced inhibition of firing rate of substantia nigra (open circles) and ventral tegmental area (solid circles) dopamine neurons in rat. Details provided in the text.

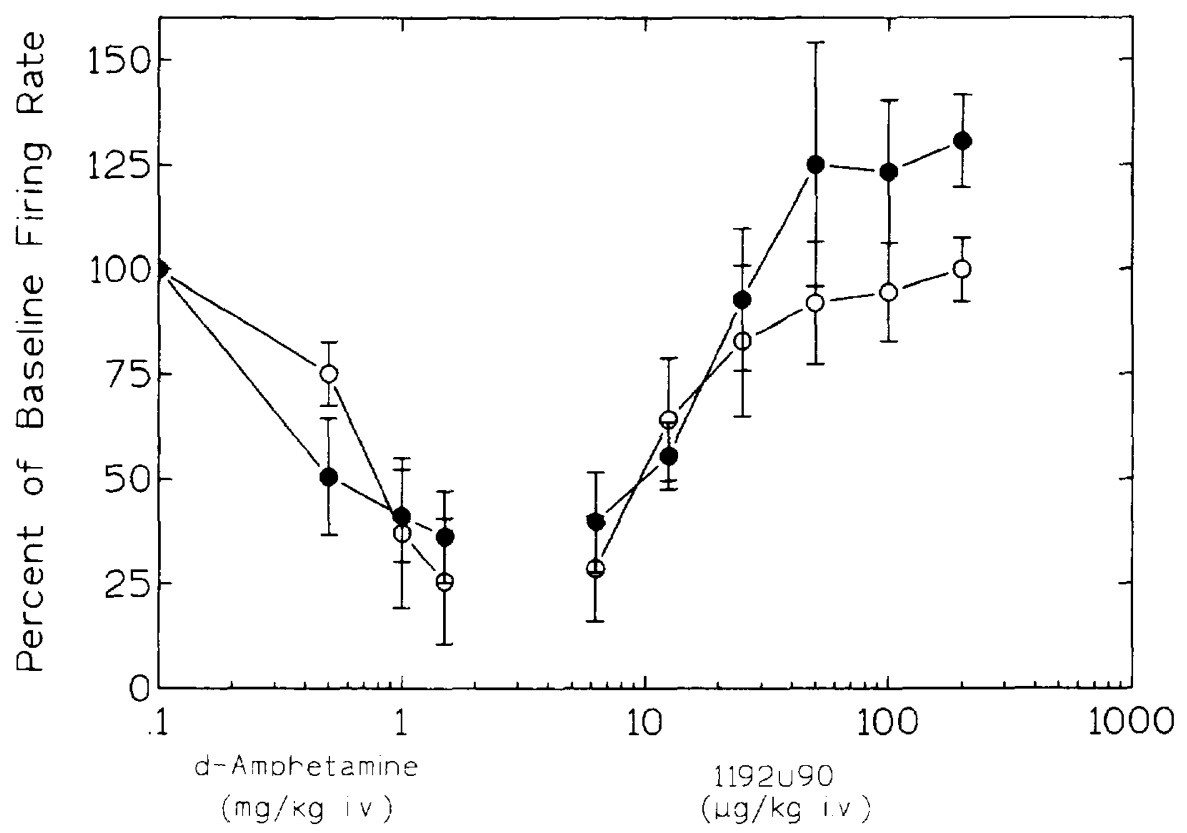

negative extracellular action potentials of approximately 0.8- to 1.2-msec duration (Rogawski and Aghajanian 1981; VanderMaelen and Aghajanian 1983; Sprouse and Aghajanian 1987; Cox et al. 1993).

In experiments with IV drug injection, single-barrel glass electrodes were used to record unit activity. Stable baseline firing was recorded for 3 to 5 minutes before drug injection. Cumulative doses of 1192U90 (6.25-200 $\mu \mathrm{g} / \mathrm{kg}$ ) were injected every 60 seconds. The effect of 1192 U90 on firing rate was determined by averaging the firing rate during the $60-\mathrm{sec}$ interval after each dose and expressing it as a percentage of the baseline rate. Responses were averaged across doses and expressed as a mean $\pm S E M$.

In iontophoresis experiments, the central recording barrel of a five-barrel glass microelectrode was filled with $2 \mathrm{M} \mathrm{NaCl}$ containing 1\% Pontamine sky blue dye (in vitro impedance 3-12 $\mathrm{M} \Omega$ ). One side barrel was filled with $0.2 \mathrm{M} \mathrm{NaCl}$ and used for current balancing (in vitro impedance, $\sim 20 \mathrm{M} \Omega$ ). Other barrels contained $1192 \mathrm{U} 90(1 \mathrm{mM}, \mathrm{pH} 3)$, the $5-\mathrm{HT}_{1 \mathrm{~A}}$ agonist ( \pm )8-OH-DPAT (20 mM, pH 5.5), or the 5- $\mathrm{HT}_{1 \mathrm{~A}}$ antagonist $\mathrm{S}(-)$-propranolol $(50 \mathrm{mM}, \mathrm{pH} 4.5)$. The in vitro impedance of drugcontaining side barrels was between 60 and $110 \mathrm{M \Omega}$ After baseline firing rates were recorded, $( \pm) 8$-OH-DPAT was applied by iontophoresis (5- to $10-\mathrm{nA}$ ejection currents) to ensure responsiveness to $5-\mathrm{HT}_{1 \mathrm{~A}}$ stimulation. When the firing rate had returned to baseline values, 1192 U90 was applied alone for 60 -sec pulses and subsequently coapplied with S(-)-propranolol. Responses were determined by expressing mean firing rate during iontophoresis as a percentage of the firing rate preceding drug application. Responses were averaged across ejection currents and expressed as a mean \pm SEM.

\section{RESULTS}

\section{Receptor Binding}

$1192 \mathrm{U} 90$ bound to $\mathrm{D}_{2} / \mathrm{D}_{3}, 5-\mathrm{HT}_{2}, 5-\mathrm{HT}_{1 \mathrm{~A}}, \alpha_{1}$ and $\alpha_{2}$ receptors with high affinity (Table 2 ). The $K_{\mathrm{i}}$ values for $1192 \mathrm{U} 90$ at $\mathrm{D}_{2} / \mathrm{D}_{3}$ and $5-\mathrm{HT}_{2}$ receptors indicated affinities about equal to those of risperidone and nine times greater than for clozapine. In addition, 1192U90 had high affinity at $5-\mathrm{HT}_{1 \mathrm{~A}}$ receptors-about 100 and 500 times higher than risperidone and clozapine. Like risperidone, 1192U90 interacted with moderate affinity at $\mathrm{D}_{1}$ receptors. $1192 \mathrm{U} 90$ showed only weak affinity at $5-\mathrm{HT}_{3}$ and $5-\mathrm{HT}_{4}$ receptors, the sigma site, and the verapamil site of L-type calcium channels (Table 3 ). It was essentially inactive at 22 other sites (Table 3 ).

\section{Uptake}

$1192 \mathrm{U} 90$ inhibited somewhat the net uptake of ${ }^{3} \mathrm{H}-\mathrm{NE}$, ${ }^{3} \mathrm{H}-5-\mathrm{HT}$, and ${ }^{3} \mathrm{H}-\mathrm{DA}$ in crude synaptosomes. The $\mathrm{IC}_{50} \mathrm{~S}$ were $2.2 \mu \mathrm{M}$ for $\mathrm{NE}, 2.4 \mu \mathrm{M}$ for $5-\mathrm{HT}$, and $6.8 \mu \mathrm{M}$ for DA uptake.

\section{Biogenic Amine Levels}

Haloperidol $1 \mathrm{mg} / \mathrm{kg}$ PO significantly increased 3,4dihydroxyphenylacetic acid (DOPAC) and homovanillic acid (HVA), the metabolites of DA ( $p \leqslant .05$ by twotailed $t$ test; Table 4 ). DOPAC was increased to $134 \%$ of control, HVA to $115 \%$. NE, DA, 5-HT, and 5-hydroxyindolacetic acid (5-HIAA) were not significantly changed.

$1192 \mathrm{U} 905 \mathrm{mg} / \mathrm{kg}$ PO also significantly increased DOPAC and HVA, to $134 \%$ and $115 \%$. The effects of 20 $\mathrm{mg} / \mathrm{kg}$ were more pronounced: DOPAC to $183 \%$, HVA 


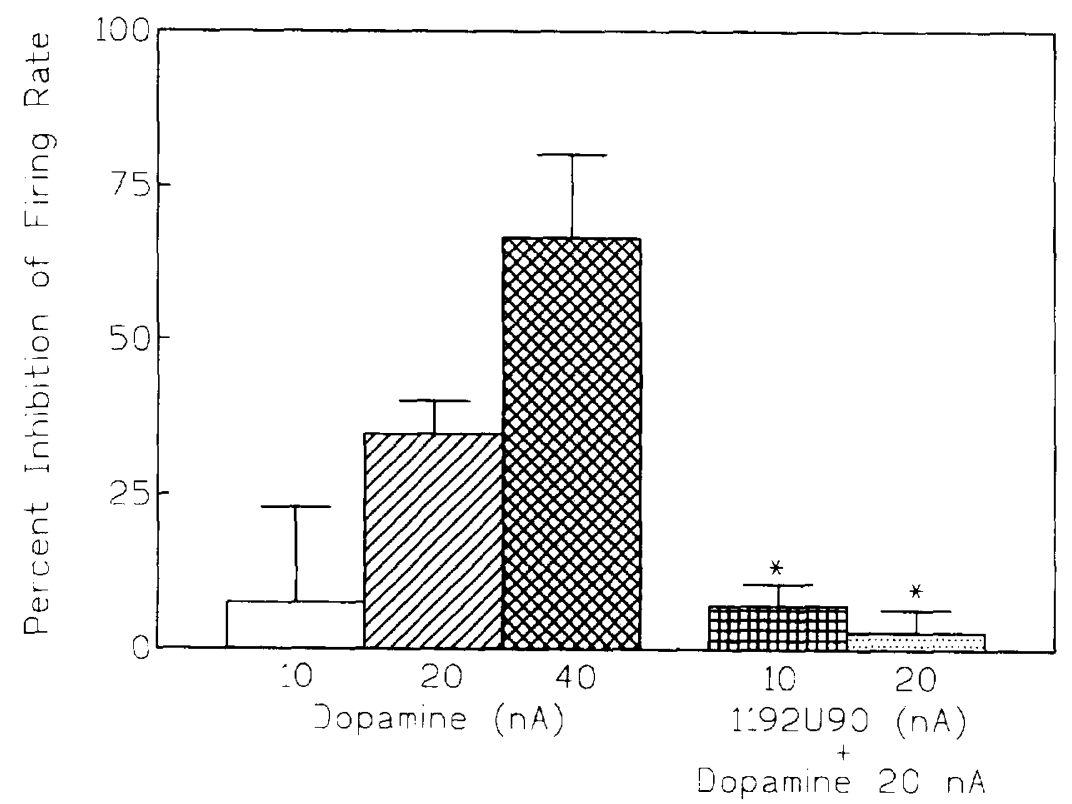

Figure 3. Effects of iontophoretically applied dopamine and 1192 U90 on firing rate of $\mathrm{SN}$ and VTA dopamine neurons in rat. Application of dopamine with ejection currents of 10,20 , and $40 \mathrm{nA}$ inhibited the firing rate of dopamine cells by $7.4 \pm 15.4 \%$ $(n=2), 34.8 \pm 5.3 \%(n=6)$, and $66.6 \pm$ $13.5 \%(n=3)$, respectively. Simultaneous application of $1192 \mathrm{U} 90$ at 10 and $20 \mathrm{nA}$ with dopamine $(20 \mathrm{nA})$ limited the inhibition of dopamine cell firing rate to $7.1 \pm 3.4 \%(n=$ 2) and $2.8 \pm 3.6 \%(n=5)$, respectively. ${ }^{*} p<$ .05 by $t$ test, 1192 U90 + dopamine versus dopamine alone. to $138 \%$. Both doses significantly increased 5-HIAA, to $117 \%$ and $128 \%$. NE, DA and 5 -HT were not significantly changed.

\section{Dopamine Neurons: Antagonism of the Inhibitory Effects of Apomorphine and $d$-Amphetamine}

Apomorphine and $d$-amphetamine each inhibited dopamine cell firing rate, and the subsequent injection of 1192 U90 reversed this inhibition (Figure 2). The average $\mathrm{ED}_{50}$ value for the reversal of apomorphine's effect by $1192 \mathrm{U} 90$ in SN and VTA was $42 \mu \mathrm{g} / \mathrm{kg}(n=7)$. This value is comparable to an $E_{50}$ value of $45 \mu \mathrm{g} / \mathrm{kg}$ for haloperidol in the same assay. 1192 U90 reversed $d$-am- phetamine-induced inhibitions with a mean $\mathrm{ED}_{50}$ value of $11.3 \pm 2.8 \mu \mathrm{g} / \mathrm{kg}$ IV ( $n=7$, SN and VTA combined). Although only a small number of animals were tested, there was no apparent difference for the reversal of amphetamine-induced inhibitions of firing rates in $\mathrm{SN}$ $\left(\mathrm{ED}_{50} 14.3 \pm 6.7 \mu \mathrm{g} / \mathrm{kg} \mathrm{IV}, n=3\right)$ and VTA $\left(\mathrm{ED}_{50} 9.0+\right.$ $1.7 \mu \mathrm{g} / \mathrm{kg} \mathrm{IV}, n=4)$.

The effects of iontophoretically applied dopamine and 1192 U90 were examined on dopamine neurons in the brains of six rats (Figure 3). Iontophoretic application of dopamine to spontaneously active cells inhibited neuronal firing rates. The simultaneous application of 1192L90 significantly limited the rate-inhibiting effect of dopamine. The baseline firing rates for these experi-

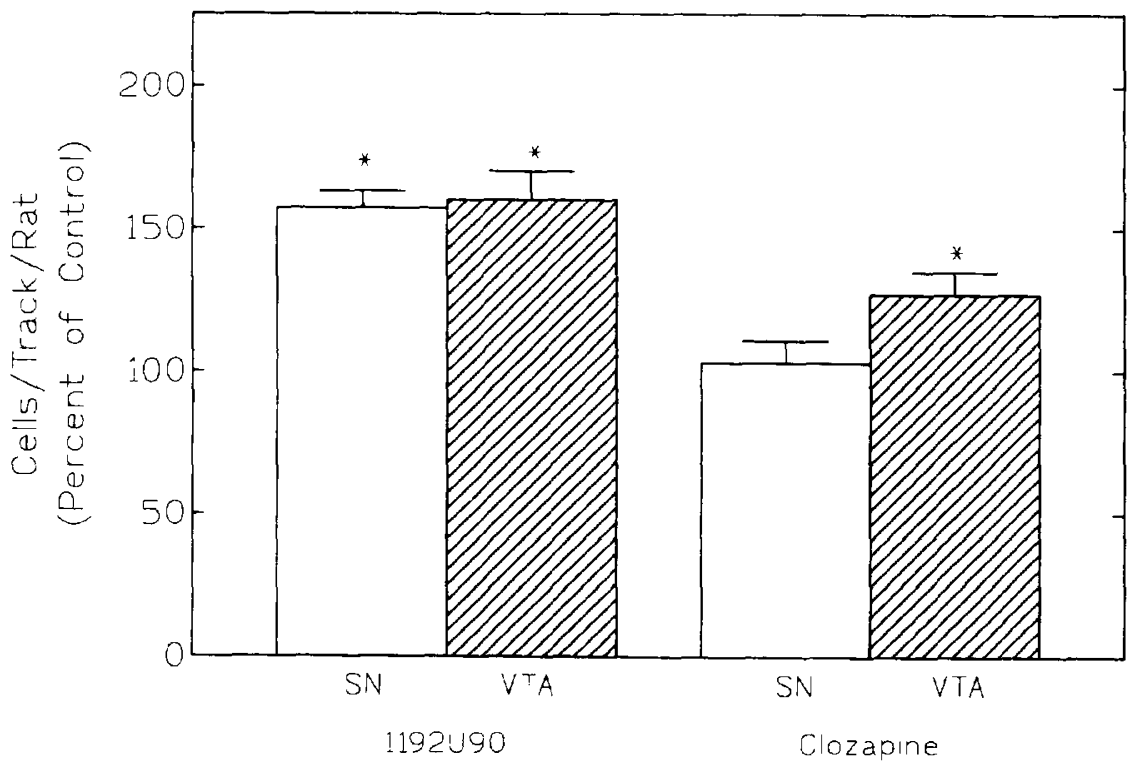

Figure 4. Effects of acute 1192 U90 $(0.8 \mathrm{mg} / \mathrm{kg} \mathrm{SC})$ and clozapine (20 $\mathrm{mg} / \mathrm{kg} \mathrm{SC}$ ) on the number of spontaneously active SN and VTA dopamine neurons in rat 2 hours after injection. Both compounds increased the number in VTA. 1192U90 increased the number in $\mathrm{SN}$, but clozapine did not. ${ }^{*} p<.05$ versus control by ANOVA; $n=7-9$ rats $/$ group . 
Figure 5. Effects of chronic $1192 \mathrm{U} 90(0.8$ $\mathrm{mg} / \mathrm{kg} /$ day SC) and clozapine $(20 \mathrm{mg} /$ $\mathrm{kg} /$ day SC) on the number of spontaneously active dopamine neurons in rat after 28 daily injections. Both compounds decrased the number in VTA but not in SN. ${ }^{* *} p<.01$ versus control by ANOVA; $n=7-10$ rats $/$ group.

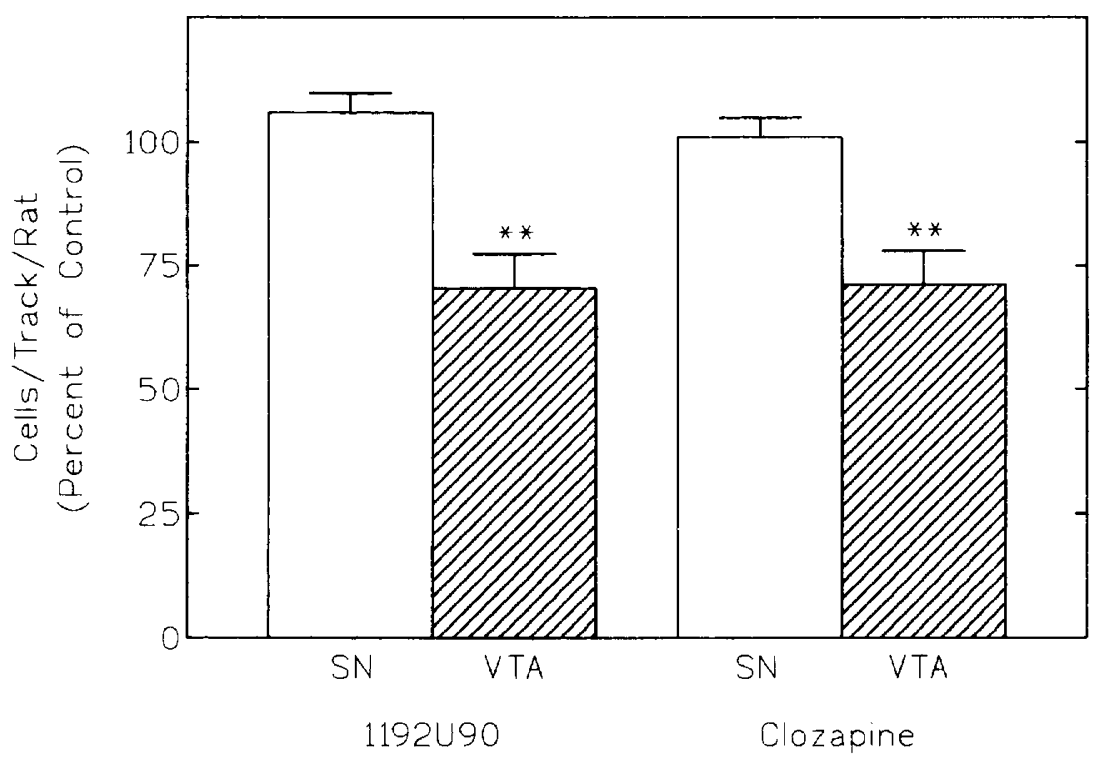

ments were (in spikes / 10 seconds): $54.3 \pm 10.3$ (DA 10 $\mathrm{nA}, n=2), 44.5 \pm 7.5(\mathrm{DA} 20 \mathrm{nA}, n=6), 38.0 \pm 10.1$ $(\mathrm{DA} 40 \mathrm{nA}, n=3), 61.3 \pm 3.2(\mathrm{DA} 20 \mathrm{nA}+1192 \mathrm{U} 9010$ $\mathrm{nA}, n=2$ ), and $44.9 \pm 6.1$ (DA $20 \mathrm{nA}+1192 \mathrm{U} 9020 \mathrm{nA}$, $n=5)$.

\section{Dopamine Neurons: Population Sampling after Acute and Chronic Administration of 1192U90 and Clozapine}

Figure 4 shows the effects of acute (2-hour) pretreatment with 1192 U90 or clozapine on dopamine cell activity. After 1192U90, the number of spontaneously active dopamine neurons in VTA and SN increased by $60 \pm$ $10 \%$ and $57 \pm 6 \%$, respectively, over vehicle control.
After clozapine, the number of spontaneously active dopamine cells in VTA increased by $27 \pm 8 \%$, but there was no change in $\mathrm{SN}$ activity (increased, $3 \pm 8 \%$ ). Mean spontaneous firing rates in both brain regions were unchanged 2 hours after either compound had been administered.

Figure 5 shows the effects of chronic dosing with 1192 U90 or clozapine on dopamine cell activity. 1192 U90 (0.8 mg/kg/day SC) decreased the number of spontaneously active dopamine neurons in VTA by $30 \pm 7 \%$ but had no effect on the number of spontaneously active dopamine cells in SN $(6 \pm 7 \%)$. Clozapine (20 $\mathrm{mg} / \mathrm{kg} /$ day SC) decreased the number of spontaneously active dopamine cells in VTA by $29 \pm 8 \%$, but had no effect on SN activity (increased, $1 \pm 4 \%$ ). Neither compound changed mean spontaneous firing rate.
Figure 6. Effect of systemic injection of 1192 U90 on the firing rate of DRN serotonin neurons in rat. The $\mathrm{ID}_{50}$ was $23 \mu \mathrm{g} / \mathrm{kg}$. Each point represents the mean \pm S.E.M. of five neurons.

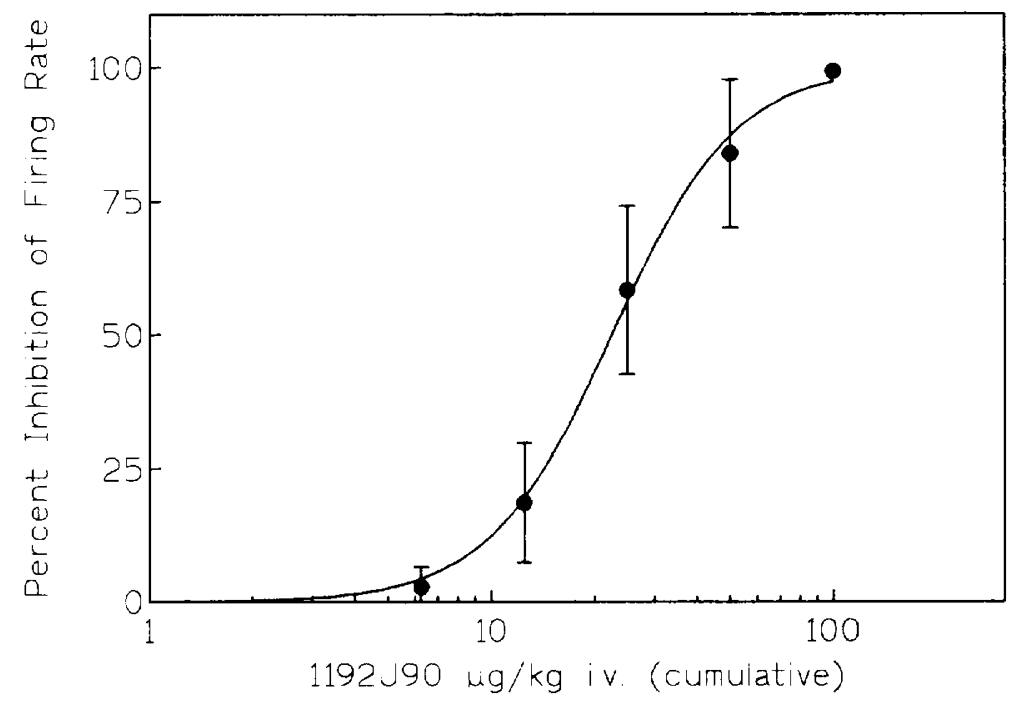




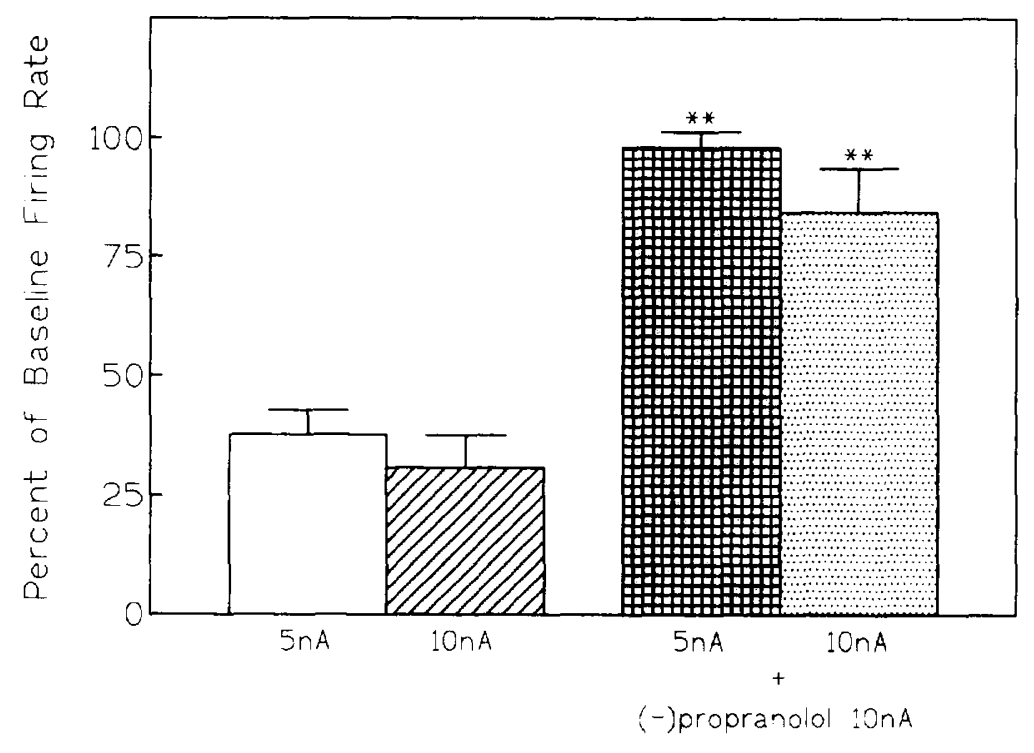

Figure 7. Effect of iontophoretic application of 8-OH-DPAT on the firing rate of DRN neurons in rat. Application of 8-OH-DPAT $(20 \mathrm{nM})$ with 5 and $10 \mathrm{nA}$ ejection currents decreased the rate by $62.3 \% \pm 5.1 \%(n=14)$ and $69.2 \% \pm 6.8 \%(n=$ 4), respectively. Simultaneous application of $\mathrm{S}(-)$-propranolol $(50 \mathrm{mM})$ with $10 \mathrm{nA}$ current limited the effects of 8-OH-DPAT on the firing rate at 5 and $10 \mathrm{nA}$ to $1.9 \pm 3.3 \%(n=7)$ and 15.5 $\pm 9.3 \%(n=4)$, respectively. ${ }^{* *} p<.01$ by $t$ test, 8 -OH-DPAT alone versus 8 -OH-DPAT $+\mathrm{S}(-)$ propranolol.

\section{Serotonin Neurons: Effects of Acute 1192U90 on Dorsal Raphe Unit Activity}

Systemic injection of $1192 \mathrm{U} 90(100 \mu \mathrm{g} / \mathrm{kg}$ IV cumulative) inhibited DRN cell firing rate by over $99 \%$. The $\mathrm{ID}_{50}$ value was $23 \mu \mathrm{g} / \mathrm{kg}$ (Figure 6).

Iontophoretic application of the $5-\mathrm{HT}_{1 \mathrm{~A}}$ agonist $( \pm) 8$-OH-DPAT inhibited DRN cell firing rate by $62.3 \pm$ $5.1 \%$ and $69.2 \pm 6.8 \%$ at ejection currents of 5 and 10 $\mathrm{nA}$, respectively. Subsequent simultaneous iontophoresis of $\mathrm{S}(-)$-propranolol at $10 \mathrm{nA}$ on to the same neurons blocked the inhibition of firing exerted by $( \pm) 8 \mathrm{OH}-$ DPAT (Figure 7).

Iontophoretic application of $1192 \mathrm{U} 90$ at 5,10 , and 40 $\mathrm{nA}$ inhibited the DRN firing rate by $23.5 \% \pm 9 \%, 40.6 \%$ $\pm 11.8 \%$, and $60.2 \% \pm 7.5 \%$, respectively (Figure 8 ). Simultaneous application of $\mathrm{S}(-)$-propranolol at $10 \mathrm{nA}$ almost completely blocked the effects of $1192 \mathrm{U} 90$.

\section{DISCUSSION}

The discovery of the atypical antipsychotic clozapine was a major advance in neuropsychopharmacology. Clozapine was different from previous neuroleptics in that it was effective against both positive and negative symptoms of schizophrenia (Kane et al. 1988; Meltzer et al. 1989; Lieberman 1993), and it caused fewer extrapyramidal side effects (Gerlach et al. 1974; Shopsin et al. 1979; Claghorn et al. 1987; Casey 1989). However, its association with agranulocytosis has limited its clinical usefulness (Idänpään-Heikkilä et al. 1975; Griffith and Saameli 1975; Lieberman et al. 1988). Because clozapine has several sites of action, there are many theories as to which neurochemical attributes are responsible and necessary for its atypical control of schizophrenia (Meltzer 1991).

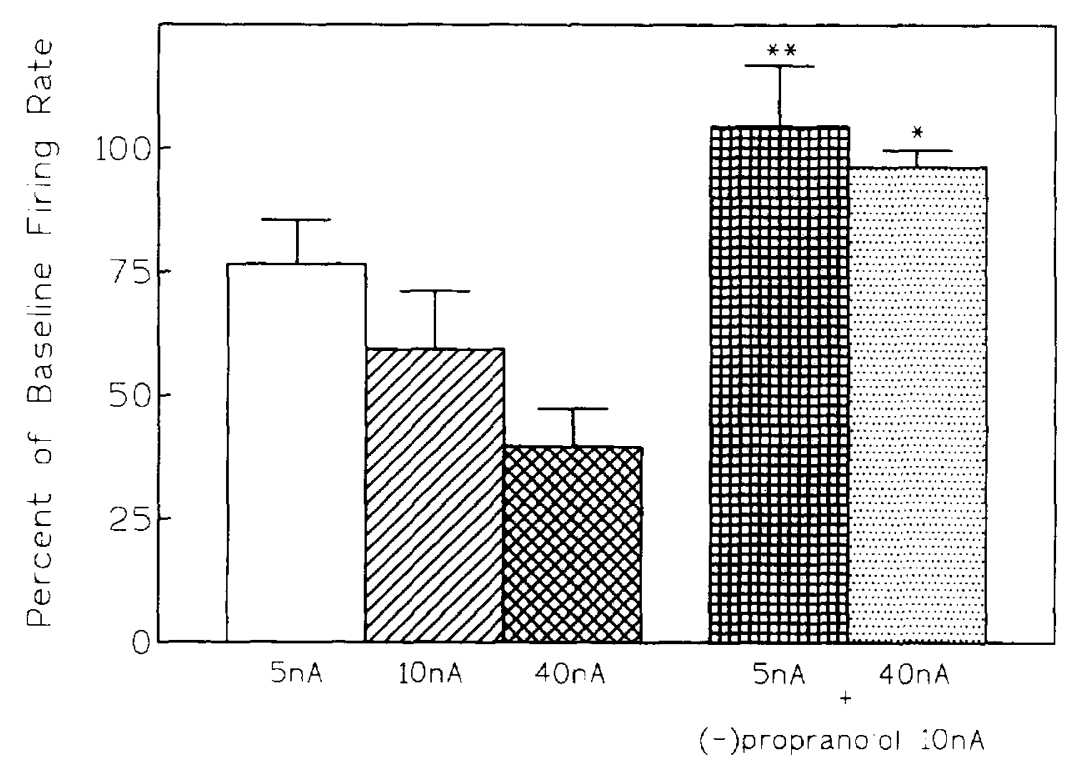

Figure 8. Effect of iontophoretic application of $1192 \mathrm{U} 90$ on the firing rate of DRN neurons in rat. Application of $1192 \mathrm{U} 90(1 \mathrm{mM})$ with 5 , 10 , and $40 \mathrm{nA}$ ejection currents decreased the rate by $23.5 \% \pm 9 \%(n=4), 40.6 \% \pm 11.8 \%(n$ $=3)$, and $60.2 \% \pm 7.5 \%(n=5)$, respectively. Simultaneous application of S(-)-propranolol $(50 \mathrm{nM})$ with $10 \mathrm{nA}$ current increased the rate by $4.5 \% \pm 12.5 \%$ at $5 \mathrm{nA}(n=2)$ and decreased the rate by $3.6 \% \pm 3.4 \%$ at $40 \mathrm{nA}(n=4) .{ }^{*} p<$ $0.5,{ }^{* *} p<.01$, by $t$ test, 1192 U90 alone versus $1192 \mathrm{U} 90+\mathrm{S}(-)$-propranolol. 
Possibly the most widely accepted theory on the neurochemical basis of schizophrenia is that hyperactivity of DA systems in the brain is at least partially responsible for psychosis (Andreasen 1988; Sunahara et al. 1993). Although there is little evidence for $D_{1}$ receptor blockade explaining the mechanism of antipsychotic activity, $D_{2}$ (and/or $D_{3}$ ) receptor antagonism is clearly implicated (Sunahara et al. 1993). Sunahara et al. (1993), point out that "clinically effective free drug concentrations of virtually all the antipsychotics correlate well with their ability to inhibit $\left[{ }^{3} \mathrm{H}\right]$-spiperone binding to the $D_{2}$ dopamine receptor." Specifically, $D_{2}$ receptor blockade in the limbic system seems to be important in controlling psychosis, whereas $D_{2}$ receptor blockade in the nigrostriatal system seems to be related to extrapyramidal side effects (Bunney 1992; Schotte et al. 1993). 1192U90, like clozapine and risperidone, binds to $D_{2}$ receptors with high affinity. The reversal of apomorphine- and $d$-amphetamine-induced inhibition of SN and VTA dopamine neuron firing rates by low doses of 1192 U 90 indicates that this compound is a potent antagonist of the dopamine receptor (or receptors) that mediates that effect (Bunney et al. 1973). Dopamine agonists act on somatodendritic $D_{2}$ or $D_{3}$ autoreceptors and inhibit the firing rates of neurons in the SN and VTA (Bunney and Aghajanian 1978; White and Wang 1984; Liu et al. 1994), whereas dopamine antagonists block or reverse this action (Bunney et al. 1973).

Acute doses of $1192 \mathrm{~L} 90(0.8 \mathrm{mg} / \mathrm{kg} \mathrm{SC}, 2$ hours before sampling) resulted in an increased number of spontaneously active SN and VTA dopamine neurons. In our hands, clozapine $(20 \mathrm{mg} / \mathrm{kg}$ SC, 2 hour presampling) had no effect on spontaneous activity of dopamine neurons in either region. The reason for this difference cannot be ascertained from the present data. Clozapine and 1192U90 clearly have different patterns of receptor binding, a factor that could underlie the differences in acute activity. This finding should not negate the potential atypical nature of 1192 U90. In fact, the acute effects of clozapine itself are not uniform across laboratories. For instance, Chiodo and Bunney (1985) reported that clozapine $(20 \mathrm{mg} / \mathrm{kg}$ PO, 1 -hour presampling) produced substantial increases in the number of active dopamine cells in both the SN and the VTA. On the other hand, White and Wang (1983) observed a selective increase in VTA activity and no effect on A9 activity after clozapine administration $(20 \mathrm{mg} / \mathrm{kg} \mathrm{SC}, 2$ hours presampling).

Chronic dosing with antipsychotic drugs produces a time-dependent inactivation of dopamine cell activity in the VTA and/or SN of rats (Chiodo and Bunney 1983; White and Wang 1983a,b). It has been suggested that inhibition of spontaneous dopamine cell activity in the VTA is related to the efficacy of these compounds as antipsychotics, whereas inactivation of $\mathrm{SN}$ dopamine neurons is related to the occurrence of extrapyramidal side-effects such as tardive dyskinesia. Most atypical antipsychotics preferentially decrease VTA activity without significantly altering spontaneous SN activity (Chiodo and Bunney 1983; White and Wang 1983b). 1192U90, like clozapine, displays this profile and may also be an atypical antipsychotic when introduced into the clinic. Very recently, the depolarization inactivation model of antipsychotic effect has come under criticism because of apparent inconsistencies with biochemical data, wide variability from study to study, and different effects when experiments are performed in awake versus anesthetized rats (Mereu et al. 1995). It has been suggested that the depolarization inactivation of dopaminergic neurons after chronic neuroleptics is an artifact secondary to a combined effect of the antipsychotic plus general anesthesia (Mereu et al. 1995). The findings underlying that suggestion (Mereu et al. 1995) do not agree, however, with those of Bunney and Grace (1978), who found depolarization inactivation in both chloral hydrate-anesthetized rats and unanesthetized rats. In our opinion, the model continues to have general predictive value for the nature of antipsychotic compounds in that chronic dosing of most, if not all antipsychotic drugs results in depolarization inactivation of VTA neurons in anesthetized rats, atypical antipsychotic drugs result in preferential inactivation of VTA versus $\mathrm{SN}$ dopamine neurons, and $\mathrm{D}_{2}$ antagonists that are not antipsychotic (e.g., metoclopramide) do not result in depolarization inactivation (White and Wang 1983a,b).

Considerable attention has recently been placed on the dopamine $\mathrm{D}_{4}$ receptor subtype (Van Tol et al. 1991). Clozapine has been reported to have selectivity for this site over the dopamine $D_{2}$ subtype (Seeman 1992; Lahti et al. 1993), although other investigators have demonstrated that this apparent selectivity may be due to the assay method used to define the affinity to the dopamine $D_{2}$ receptor subtype (Malmberg et al. 1993; Durcan et al. 1995). In parallel experiments using ${ }^{3} \mathrm{H}$-spiperone to assess affinities at $D_{2}$ and $D_{4}$ receptors Durcan et al. (1995) found that 1192U90, like clozapine, was selective for $D_{4}$ receptors over $D_{2}$ with $K_{d}$ values of 0.21 versus $0.12 \mathrm{nM}$, respectively. Neither clozapine nor $1192 \mathrm{U} 90$ were selective if ${ }^{3} \mathrm{H}$-raclopride was used to determine affinity at $\mathrm{D}_{2}$ receptors. Thus, it currently remains uncertain which receptor subtype, if either, underlies the antipsychotic efficacy of clozapine.

Another theory on the mechanism of atypical antipsychotics that has come from studying clozapine's unique profile proposes that a balance of $5-\mathrm{HT}_{2}$ and $\mathrm{D}_{2}$ antagonism is responsible for atypical antipsychotic activity and reduced side effect profiles (Meltzer 1991). Studies in this vein have indicated that higher occupancy of $5-\mathrm{HT}_{2}$ receptors relative to $\mathrm{D}_{2}$ receptors may be responsible for reduced incidence of extrapyramidal side effects (Schotte et al. 1993; Stockmeier et al. 1993). 
1192U90, like clozapine and risperidone, has a 10-fold higher affinity for $5-\mathrm{HT}_{2}$ than for $\mathrm{D}_{2}$. This could lead to higher occupancy of $5-\mathrm{HT}_{2}$ receptors than $\mathrm{D}_{2}$ receptors. A potential for reduced side effect liability with 1192490 is further suggested by its weakness in antagonizing apomorphine-induced stereotypy and catalepsy (Rigdon et al. 1996).

The dose-related inhibition of DRN firing after IV injections of $1192 \mathrm{U} 90$ suggests that it is a $5-\mathrm{HT}_{1 \mathrm{~A}}$ agonist. $1192 \mathrm{U} 90$, with an $\mathrm{ID}_{50}$ of $23 \mu \mathrm{g} / \mathrm{kg}$, is less potent than the $5-\mathrm{HT}_{1 \mathrm{~A}}$ agonist $( \pm) 8-\mathrm{OH}-\mathrm{DPAT}\left(\mathrm{ID}_{50}=1.5 \mu \mathrm{g} / \mathrm{kg}\right.$; Cox et al. 1993) but similar in potency to ipsapirone (Sprouse and Aghajanian 1987; Cox et al. 1993), a 5-HT $1 \mathrm{~A}$ receptor ligand with anxiolytic properties (Traber and Glaser 1987).

Direct application of $1192 \mathrm{U} 90$ by microiontophoresis also decreased DRN cell firing rate, an effect that may be mediated by direct stimulation of $5-\mathrm{HT}_{1 \mathrm{~A}}$ autoreceptors on DRN cell bodies and dendrites. Although 192 U90 is a weak inhibitor of serotonin uptake $\left(\mathrm{IC}_{50}=\right.$ $2.5 \mu \mathrm{M})$, pharmacokinetic studies performed with dosing schemes identical to those of the electrophysiological experiments produced brain levels of $1192 \mathrm{U} 90$ that were 1,000 times lower than the in vitro $\mathrm{IC}_{50}$ for inhibition of serotonin uptake (K. M. Hedeen, personal communication). This would indicate that the effect of 1192 U90 on DRN firing rate is not due to inhibition of uptake, but is, rather, a direct action. The inhibition of DRN firing rate by 1192 U90 or (土)8-OH-DPAT was blocked by simultaneous iontophoretic application of $\mathrm{S}(-)$-propranolol, a $5-\mathrm{HT}_{1 \mathrm{~A}}$ antagonist, confirming that the effect was mediated to a major extent by $5-\mathrm{HT}_{1 \mathrm{~A}} \mathrm{re}-$ ceptors (Sprouse and Aghajanian 1986). Other antipsychotic drugs such as methiothepin, clozapine, and thioridazine also inhibit DRN firing rate; however, their effects correlate $w$ ith their affinities at $\alpha_{1}$ receptors (Gallagher and Aghajanian 1976). Our results do not rule out some contribution from $\alpha_{1}$ blockade to the inhibition of DRN firing rate by 1192 L90; nevertheless, antagonism of the inhibition by iontophoretically applied $S(-)$-propranolol supports the conclusion that the effect of $1192 \mathrm{U} 90$ is primarily due to $5-\mathrm{HT}_{1 \mathrm{~A}}$ stimulation.

The clinical relevance of an antipsychotic drug with $5-\mathrm{HT}_{1 \mathrm{~A}}$ agonist actirity is not known, but this property may confer positive attributes. Compounds with $5-\mathrm{HT}_{1 \mathrm{~A}}$ agonist or partial agonist effects include buspirone, ipsapirone, and gepirone, which are anxiolytic (Traber and Glaser 1987). The results of animal behavioral tests by Rigdon et al. (1996) suggest an anxiolytic potential for 1192U90. Anxiety is often a component of schizophrenia; therefore, coincident anxiolytic activity in an antipsychotic drug would be very desirable. In addition to potential anxiolytic effect, agonist activity at $5-\mathrm{HT}_{1 \mathrm{~A}}$ receptors might also contribute to the "atypical" antipsychotic profile of 1192 U90. There have been previous attempts to design compounds possessing $\mathrm{D}_{2}$ antago- nism and $5-\mathrm{HT}_{1 \mathrm{~A}}$ agonism with the hope of developing an atypical antipsychotic (Lowe et al. 1991). A rationale for such a combination of activities is based on the observation that buspirone, ipsapirone, and $( \pm) 8-\mathrm{OH}-$ DPAT reverse haloperidol-induced catalepsy (McMillen et al. 1988; Hicks 1990). Furthermore, (土)8-OH-DPAT suppresses conditioned avoidance behavior and selectively decreases limbic dopamine synthesis (Ahlenius 1989).

1192U90, like clozapine, risperidone, and many other antipsychotic drugs, has high affinity for the $\alpha_{1}$ receptor. Because of this high affinity for the $\alpha_{1}$ receptor, it has been proposed that $\alpha_{1}$ blockade may be a component for antipsychotic activity (Cohen and Lipinski 1986; Baldessarini et al. 1992; Sleight et al. 1993) and may mediate differential effects on SN and VTA dopamine neurons after chronic dosing (Chiodo and Bunney 1983). Cohen and Lipinski (1986) demonstrated that, following chronic treatment with clozapine, thioridazine, chlorpromazine, fluphenazine, or haloperidol, $\alpha_{1}$ receptors were upregulated, indicating a physiologically significant in vivo blockade of these receptors. In contrast, $\mathrm{D}_{2}$ receptor upregulation occurred only after chronic fluphenazine or haloperidol. This suggests that $\alpha_{1}$ receptor blockade may be involved in the mechanism of therapeutic effect of antipsychotic drugs (Cohen and Lipinski 1986). Electrophysiological studies add evidence for a noradrenergic role in the modulation of dopamine neuron activity in the VTA (Chiodo and Bunney 1983; Grenhoff and Svensson 1994; Andersson et al. 1994). However, it is difficult to ascribe the atypical nature of some antipsychotics to $\alpha_{1}$ antagonism because haloperidol, which is not atypical, is nearly equipotent at this receptor compared to clozapine (Hacksell et al. 1995). A recent review of the preclinical effects of antipsychotic compounds concluded that there is no evidence that $\alpha_{1}$ blockade is a positive attribute in an antipsychotic drug (Jackson et al. 1994).

It is well established that administration of antipsychotic drugs increase the level of DA metabolites in brain (Carlsson and Lindqvist 1963; Bunney et al. 1973; Bürki et al. 1975; Coward 1992). This reflects an increase in DA turnover. Typical antipsychotic drugs like haloperidol increase DA turnover by activating feedback systems to presynaptic dopamine neurons following DA receptor blockade (Bürki et al. 1974, 1975). Clozapine increases both DA and metabolite levels in the striatum by increasing DA release in response to $D_{1}$ receptor blockade but not $\mathrm{D}_{2}$ blockade (Imperato and Angelucci, 1988; Coward 1992). Acute administration of $1192 \mathrm{U} 90$ (5 and $20 \mathrm{mg} / \mathrm{kg}$ PO) increased levels of DOPAC and HVA as well as 5HIAA, maybe because of its interaction with 5-HT receptors. These effects are probably due to receptor blockade because these doses of 1192 U90 yield brain levels that are about 100 -fold lower than the $\mathrm{IC}_{50}$ ) values for inhibition of uptake of dopa- 
mine or serotonin (K. M. Hedeen, personal communication).

It remains to be determined which neurochemical characteristics are necessary to obtain good antipsychotic activity with minimal side effects. 1192U90, like most new antipsychotic compounds, has high affinity for $\mathrm{D}_{2}, 5-\mathrm{HT}_{1}, \mathrm{~A}-\mathrm{HT} \mathrm{H}_{2}$, and $\alpha_{1}$ receptors. Our in vivo single-unit recordings indicate that $1192 \mathrm{U} 90$ is a potent dopamine $\mathrm{D}_{2} / \mathrm{D}_{3}$ antagonist as well as a $5-\mathrm{HT}_{1 \mathrm{~A}}$ agonist. Population sampling of SN and VTA dopamine neuronal activity show that chronically administered 1192 40 selectively decreases the activity of VTA dopamine neurons that are associated with limbic projections. These properties, taken together with behavioral data, lead us to propose that 1192 U90 will have an atypical antipsychotic profile in the clinic.

\section{REFERENCES}

Aghajanian GK, Bunney BS (1977): Dopamine "autoreceptors": Pharmacological characterization by microiontophorectic single cell recording studies. Naunyn Schmiedebergs Arch Pharmacol 297:1-7

Ahlenius S (1989): Antipsychotic-like properties of the $5-\mathrm{HT}_{1 \mathrm{~A}}$ agonist 8-OH-DPAT in the rat. Pharmacol Toxicol 64:3-5

Andersson JL, Marcus M, Nomikos GG, Svensson TH (1994): Prazosin modulates the changes in firing pattern and transmitter release induced by raclopride in the mesolimbic, but not in the nigrostriatal dopaminergic system. Xaunyn Schmiedbergs Arch Pharmacol 349:236-243

Andreasen, $\mathrm{NC}(1988)$ : Brain imaging: Applications in psychiatry. Science 239:1381-1388

Bahouth SW, Musacchio IM (1985): Specific binding of $\left[{ }^{3} \mathrm{H}\right]$-substance $\mathrm{P}$ to the rat submaxillary gland. J Pharmacol Exp Ther 234:326-336

Baldessarini RJ, Huston-Lyons D, Campbell A, Marsh E, Cohen BM (1992): Do central antiadrenergic actions contribute to the atypical properties of clozapine? Br J Psychiatry 17 (suppl):12-16

Billard W, Ruperto V, Crosby G, lorio LC, Barnett A (1984): Characterization of the binding of $3 \mathrm{H}-\mathrm{SCH} 23390$, a selective $\mathrm{D}_{1}$ receptor antagonist ligand, in rat striatum. Life Sci 35:1885-1893

Bunney BS (1992): Clozapine: A hvpothesized mechanism for its unique clinical profile. Br ] P'sychiatry 17:(suppl) $17-21$

Bunney BS, Aghajanian GK (1978): d-Amphetamine-induced depression of central dopamine neurons: Evidence for mediation by both autoreceptors and a striatonigral feedback pathway. Naunvn-Schmiedebergs Arch Pharmacol 3()4:25j-26i

Bunney BS, Grace AA (1978): Acute and chronic haloperidol treatment: Comparison of effect on nigral dopaminergic activity: Life Sci 23:1715-1728

Bunney BS, Walters JR, Roth RH, Aghajanian GK (1973): Dopaminergic neurons: Effect of antipsychotic drugs and amphetamine on single cell activity. J Pharmacol Exp Ther 185:560-571
Burcher E, Buck SH, Lovenberg W (1986): Characterization and autoradiographic localization of multiple tachykinin binding sites in gastrointestinal tract and bladder. J Pharmacol Exp Ther 236:819-831

Bürki HR, Ruch W, Asper H (1975): Effects of clozapine, thioridazine, perlapine and haloperidol on the metabolism of the bigenic amines in the brain of the rat. Psychopharmacologia (Berl.) 41:27-33

Bürki HR, Ruch W, Asper H, Baggiolini M, Stille G (1974): Effect of single and repeated administration of clozapine on the metabolism of dopamine and noradrenaline in the brain of the rat. Eur J Pharmacol 27:180-190

Carlsson A, Lindqvist M (1963): Effect of chlorpromazine and haloperidol on the formation of 3-methoxytyramine and normetanephrine in mouse brain. Acta Pharmacol Toxicol 20:140-144

Casey DE (1989): Clozapine: Neuroleptic-induced EPS and tardive dyskinesia. Psychopharmacol 99(suppl):S47-S53

Cheng JB, Townley RG (1984): Identification of leukotriene $\mathrm{D}_{4}$ receptor binding sites in guinea pig lung homogenates using $\left[{ }^{3} \mathrm{H}\right]$-leukotriene $\mathrm{D}_{4}$. Biochem Biophys Res Commun 118:20-26

Cheng Y, Prusoff WH (1973): Relationship between the inhibition constant $\left(K_{i}\right)$ and the concentration of inhibitor which causes 50 percent inhibition $\left(I_{50}\right)$ of an enzymatic reaction. Biochem Pharmacol 22:3099-3108

Chiodo LA, Bunney BS (1983): Typical and atypical neuroleptics: Differential effects of chronic administration on the activity of $\mathrm{A} 9$ and $\mathrm{A} 10$ midbrain dopaminergic neurons. J Neurosci 3:1607-1619

Chiodo LA, Bunney BS (1985): Possible mechanisms by which repeated clozapine administration differentially affects the activity of two populations of midbrain dopamine neurons. J Neurosci 5:2539-2544

Claghorn J, Honigfeld G, Abuzzahab FS Sr, Wang R, Steinbook R, Tauson B, Klerman G (1987): The risks and benefits of clozapine v'ersus chlorpromazine. J Clin Psychopharmacol 7:377-384

Cohen BM, Lipinski JF (1986): In vivo potencies of antipsychotic drugs in blocking alpha $a_{1}$ noradrenergic and dopamine $\mathrm{D}_{2}$ receptors: Implications for drug mechanisms of action. Life Sci 39:2571-2580

Coward DM (1992): General pharmacology of clozapine. Br J Psychiatry 17(suppl):5-11

Cox RF, Neumeyer JL, Waszczak BL (1988): Effects of $\mathrm{N}$-npropylnorapomorphine enantiomers on single unit activity of substantia nigra pars compacta and ventral tegmental area dopamine neurons. J Pharmacol Exp Ther 247:355-362

Cox RF, Meller E, Waszczak BL (1993): Electrophysiological evidence for a large receptor reserve for inhibition of dorsal raphe neuronal firing by $5-\mathrm{HT}_{1 \mathrm{~A}}$ agonists. Synapse 14:297-304

D'Ambra TE, Estep KG, Bell MR, Eissenstat MA, Josef KA, Ward SJ, Haycock DA, Baizman ER, Casiano FM, Beglin VC, Chippari SM, Grego JD, Kullnig RK, Daley GT (1992): Conformationally restrained analogues of Pravadoline: Nanomolar potent, enantioselective, (aminoalkyl)indole agonists of the cannabinoid receptor. J Med Chem 35 : 124-1.35

Dewar KM, Montreuil B, Grondin L, Reader TA (1989): Dopamine $D_{2}$ receptors labeled with $\left[{ }^{3} \mathrm{H}\right]$ raclopride in 
rat and rabbit brains. Equilibrium binding, kinetics, distribution and selectivity. J Pharmacol Exp Ther 250:696706

Durcan MJ, Rigdon GC, Norman MH, Morgan PF (1995): Is clozapine selective for the dopamine $\mathrm{D}_{4}$ receptor? Life Sci 57:PL275-283

Eshleman A], Murray TF (1990): Dependence on gammaaminobutyric acid of pyrethroid and $4^{\prime}$-chlorodiazepam modulations of the binding of $t-[355]$-butylbicyclophosphorothionate in piscine brain. Neuropharmacology 29:641-648

Ferris RM, Tang FL (1979): Comparison of the effects of the isomers of amphetamine, methylphenidate and deoxypipradol on the uptake of $1-\left[{ }^{3} \mathrm{H}\right]$-norepinephrine and $\left[{ }^{3} \mathrm{H}\right]$-dopamine by synaptic resicles from rat whole brain, striatum and hypothalamus. I Pharmacol Exp Ther 210:244-428

Gallagher DW, Aghajanian GK (1976): Effect of antipsychotic drugs on the firing of dorsal raphe cells. I. Role of adrenergic system. Eur J Pharmacol 39:341-355

Gerlach J, Koppelhus P, Helweg E, Monrad A (1974): Clozapine and haloperidol in a single-blind cross-over trial: Therapeutic and biochemical aspects in the treatment of schizophrenia. Acta Psychiatr Scand 50:410-424

Goedert M, Pittaway K, Williams BJ, Emson PC (1984): Specific binding of tritiated neurotensin to rat brain membranes: Characterization and regional distribution. Brain Res 304:71-81

Gopalakrishnan M, Johnson DE, Janis RA, Triggle DJ (1991): Characterization of binding of the ATP-sensitive potassium channel ligand, ${ }^{3} \mathrm{H}$-glyburide, to neuronal and muscle preparations. J Pharmacol Exp Ther 257:11621171

Gould R], Murphy KM. Snyder SH (1982): [ $\left.{ }^{3} H\right]-N i t r e n-$ dipine-labeled calcium channels discriminate inorganic calcium agonists and antagonists. Proc Nat Acad Sci U S A $79: 3656-3660$

Gozlan H, El Mestikawy S, Pichat L, Glowinski J. Hamon M (1983): Identification of presynaptic serotonin autoreceptors using a new ligand: ${ }^{3}$ H-PAT. Nature 305:140-142

Greenberg DA, U'Prichard DC, Snyder SH (1976): Alphanoradrenergic receptor binding in mammalian brain: Differential labeling of agonist and antagonist states. Life Sci 19:69-76

Grenhoff I, Svensson TH (1994): Prazosin modulates the firing pattern of dopamine neurons in the rat ventral tegmental area. Eur J Pharmacol 233:79-84

Griffith RW, Saameli K (1975): Clozapine and agranulocytosis. Lancet 2(7936):657

Grossman CJ, Kilpatrick GJ, Bunce KT (1993): Development of a radioligand binding assay for $5-\mathrm{HT}_{4}$ receptors in guinea-pig and rat brain. Brit J Pharmacol 109:618-624

Hacksell U, Jackson DM, Mohell N (1995): Dose the dopamine receptor subtype selectivity of antipsychotic agents provide useful leads for the development of novel therapeutic agents? Pharmacol Toxicol 76:320-324

Hicks PB (1990): The effect of serotonergic agents on haloperidol-induced catalepsy: Life Sci 47:1609-1615

Hwang S, Lam M, Pong S (1986): Ionic and GTP regulation of binding of platelet-activating factor to receptors and platelet-activating factor-induced activation of GTPase in rabbit platelet membranes. J Biol Chem 261:532-537
Idänpään-Heikkilä J, Alhava E, Olkinuora M, Palva I (1975): Clozapine and agranulocytosis. Lancet 2(7935):611

Imperato A, Aupclucci L (1988): The effects of clozapine and fluperlapine on the in vivo release and metabolism of dopamine in the striatum and in the prefrontal cortex of freely moving rats. Psychopharmacology Bulletin 25:383-389

Jackson DM, Ryan C, Evenden J, Mohell N (1994): Preclinical findings with new antipsychotic agents: What makes them atypical? Acta Psychiatr Scand 89(suppl 380):4148

Kalaria RN, Andom AC, Tabaton M, Whitehouse PJ, Harik SI, Unnerstall JR (1989): Adrenergic receptors in aging and Alzheimer's disease: Increased $\beta_{2}$-receptors in prefrontal cortex and hippocampus. J Neurochem 53:17721781

Kane J, Honigfeld G, Singer J, Meltzer H (1988): Clozapine for the treatment-resistant schizophrenic. Arch Gen Psychiatry 45:789-796

Lahti RA, Evans DL, Stratman NC, Figur LM (1993): Dopamine $\mathrm{D}_{4}$ versus $\mathrm{D}_{2}$ receptor selectivity of dopamine receptor antagonists: Possible therapeutic implications. Eur J Pharmacol 236:483-486

Lieberman JA, Johns CA, Kane JM, Rai K, Pisciotta AV, Saltz BL, Howard A (1988): Clozapine-induced agranulocytosis: Non-cross-reactivity with other psychotropic drugs. J Clin Psychiatry 49:271-277

Lieberman JA (1993): Understanding the mechanism of action of atypical antipsychotic drugs. Br J Psychiatry 22:(suppl)7-18

Leysen JE, Niemegeers CJ, Van Nueten JM, Laduron PM (1982): [ [ $\mathrm{H}]$ Ketanserin ( 41468 ), a selective ${ }^{3} \mathrm{H}$-ligand for serotonin 2 receptor binding sites. Binding properties, brain distribution, and functional role. Mol Pharmacol 21:301-314

Liu J-C, Cox RF, Greif GJ, Freedman JE, Waszczak BL (1994): The putative dopamine $\mathrm{D}_{3}$ receptor agonist $7-\mathrm{OH}$ DPAT: Lack of mesolimbic selectivity. Eur J Pharmacol 264:269-278

Lowe JA III, Seeger TF, Nagel AA, Howard HR, Seymour PA, Hevm JH, Ewing FE, Newman ME, Schmidt AW, Furman JS, Vincent LA, Maloney PR, Robinson GL, Reynolds LS, Vinick FJ (1991): 1-Naphthylpiperaszine derivatives as potential atypical antipsychotic agents. J Med Chem 34:1860-1866

Lynch CJ, Blackmore PF, Charest R, Exton JH (1985): The relationships between receptor binding capacity for norepinephrine, angiotensin II, and vasopressin and release of inositol triphosphate, $\mathrm{Ca}^{2+}$ mobilization, and phosphorylase activation in rat liver. Mol Pharmacol 28:93-99

Malmberg A, Jackson DM, Eriksson A-M, Mohell N (1993): Unique binding characteristics of antipsychotic agents interacting with human $\mathrm{D}_{2 \mathrm{~A}}, \mathrm{D}_{2 \mathrm{~B}}$, and $\mathrm{D}_{3}$ receptors. Mol Pharmacol 43:749-754

Marangos PJ, Deckert J (1987): [ $\left.{ }^{3} \mathrm{H}\right]$ Dipyridamole binding to guinea pig brain membranes: Possible heterogeneity of central adenosine uptake sites. J Neurochem 48:12311236

Marangos PJ, Martino A.M (1981): Studies on the relationship of gamma-aminobutyric acid-stimulated diazepam bind- 
ing and the gamma-aminobutyric acid receptor. Mol Pharmacol 20:16-21

Mc.Millen BA, Scott SM, Davanzo EA (1988): Reversal of neuroleptic-induced catalepsy by novel aryl-piperazine anxiolytic drugs. J Pharm Pharmacol 40:885-887

Meltzer, HY (1991): The mechanism of action of novel antipsvchotic drugs. Schizophr Bull 17:265-287

Meltzer HY (1992): The importance of serotonin-dopamine interactions in the actions of clozapine. Br J Psychiatry 17:(suppl)22-29

Meltzer HY, Bastani B, Young Kwon K, Ramierz LF, Sharpe (1989): A prospective study of clozapine in treatmentresistant schizophrenic patients. Psychopharmacol 99: S68-S72

Mereu G, Lilliu V, Vargiu P, Muntoni LS, Diana M (1995): Depolarization inactivation of dopamine neurons: An artefact? I Neurosci 15:114t-1149

Minneman KP, Hegstrand LR, Molinoff PB (1979): Simultaneous determination of beta 1 and beta 2 adrenergic receptors in tissues containing both receptor subtypes. Mol Pharmacol 16:3t-36

Mussap CI, Burcher E (1990): [ [25]]-BH Scyliorhinin II: A novel, selective radioligand for the $\mathrm{NK}_{3}$ receptor in rat brain. Peptides 11:827-836

Nelson DR, Thomas DR (1989): ['H]-BRL+3694 (Granisetron), a specific ligand for $5-\mathrm{HT}_{3}$ binding sites in rat brain cortical membranes. Biochem Pharmacol 38:16931695

Peroutka SI (1986): Pharmacological differentiation and characterization of $5-\mathrm{HT}_{1 \mathrm{~A}}, 5-\mathrm{HT}_{1 \mathrm{~B}}$, and $5-\mathrm{HT}_{1 \mathrm{C}}$ binding sites in rat frontal cortex. I Neurochem 47:529-540

Rardon DP, Cefali DC, Mitchell RD, Seiler SM, Hathawav DR, Jone's LR (1990): Digestion of cardiac and skeletal muscle junctional sarcoplasmic reticulum vesicles with calpain II. Effects on the $\mathrm{Ca}^{2+}$ release channel. Circ Res $67: 84-96$

Revnolds 1], Snow man AM, Synder SH (1986): (-)-["H]Desmethoxverapamil labels multiple calcium channel modulator receptors in brain and skeletal muscle membranes: Differentiation by temperature and dihvdropyridines. J Pharmacol Exp Therap 237:731-738

Rigdon GC, Vorman MH, Cooper BR, Howard JL, Boncek VM, Faison WI., Nanry KP, Pollard GT (1996): 1192L90) in animal tests that predict antipsychotic efficacy, anxiolysis, and extrapyramidal side effects. Neuropsychopharmacology 15:231-242

Rogawaski MA, Aghajanian GK (1981): Serotonin autoreceptors on dorsal raphe neurons: Structure-activity relationships of tryptamine analogs. J Neurosci 1:1148-1154

Rouot B, Quennedey MC, Schwartz J (1982): Characteristics of the $\left[{ }^{3} \mathrm{H}\right]-y$ ohimbine binding on rat brain alphasadrenoceptors. Nauny'n-Schmiedebergs Arch Pharmäcol 321:253-259

Saito A, Goldfine ID, Williams JA (1981): Characterization of receptors for cholecystolinin and related peptides in mouse cerebral cortex. I Neurochem 37:483-490

Schotte A, Janssen PF, Megens AA, Levsen JE (1993): Occupancy of central neurotransmitter receptors by risperidone, clozapine and haloperidol, measured ex vivo by quantiative autoradiography. Brain Res 631:191-202

Seeman P' (1992): Dopamine receptor sequences: Therapeutic levels of neuroleptics occupy $\mathrm{D}_{2}$ receptors, clozapine occupies $D_{4}$. Neuropsychopharmacology 7:261-284

Shopsin B, Klein H, Aaronsom M, Collora M (1979): Clozapine, chlorpromazine, and placebo in newly hospitalized, acutely schizophrenic patients: A controlled, doubleblind comparison. Arch General Psychiatry 36:657-664

Sleight AJ, Koek W, Bigg DCH (1993): Binding of antipsychotic drugs at alpha $\mathrm{A}^{-}$and alpha $\mathrm{B}$-adrenoceptors: Risperidone is selective for the alpha $1 \mathrm{~B}$-adrenoceptors. Eur I Pharmacol 238:407-410

Slotkin TA, Cowdery TS, Orband L, Pachman S, Whitmore WL (1986): Effects of neonatal hypoxia on brain development in the rat: Immediate and long-term biochemical alterations in discrete regions. Brain Res 374:63-74

Sprouse JS, Aghajanian GK (1986): (-)-Propranolol blocks the inhibition of serotonergic dorsal raphe cell firing by 5- $\mathrm{HT}_{1 \text { id }}$ selective agonists. Eur J Pharmacol 128:295-298

Sprouse JS, Aghajanian GK (1987): Electrophysiological responses of serotonergic dorsal raphe neurons to $5 \mathrm{HT}_{1 \mathrm{~A}}$ and $5 \mathrm{HT}_{1 \mathrm{~B}}$ agonists. Synapse 1:3-9

Stockmeier CA, DiCarlo JJ, Zhang Y, Thompson P, Meltzer HY (1993): Characterization of typical and atypical antipsychotic drugs based on in vivo occupancy of serotionin $_{2}$ and dopamine 2 receptors. J Pharmacol Exp Ther 266:1374-1384

Sunahara RK, Seeman P, Van Tol HHM, Niznik HB (1993): Dopamine receptors and antipsychotic drug response. Br J Psychiatry 22(suppl):31-38

Tam SW (1983): Naloxone-inaccessible sigma receptor in rat central nervous system. Proc Nat Acad Sci U S A 80: 6703-6707

Tarsy D (1983): Neuroleptic-induced extrapyramidal reactions: Classification, description and diagnosis. Clin Neuropharmacol 6(suppl 1):S9-S26

Traber J, Glaser T (1987): $5-\mathrm{HT}_{1 \mathrm{~A}}$ receptor-related anxiolytics. Trends Pharmacol Sci 8:432-437

VanderMaelen CP, Aghajanian GK (1983): Electrophysiological and pharmacological characterization of sertonergic dorsal raphe neurons recorded extracellularly and intracellularly in rat brain slices. Brain Res 289:109-119

Van Tol HHm, Bunzow JR, Guan H-C, Sunahara RK, Seeman P, Niznik HB, Civelli O (1991): Cloning of the gene for a human dopamine $\mathrm{D}_{4}$ receptor with high affinity for the antipsychotic clozapine. Nature 350:610-614

Watson M, Yamamura HI, Roeske WR (1983): A unique regulatory profile and regional distribution of $\left[{ }^{3} \mathrm{H}\right]$ pirenzepine binding in the rat provide evidence for distinct $M_{1}$ and $M_{2}$ muscarinic receptor subtypes. Life Sci 32:3001-3011

Waggoner WG, Genova SL, Rash VA (1992): Kinetic analyses demonstrate that the equilibrium assumption does not apply to $\left[{ }^{125} \mathrm{I}\right]-\mathrm{end}$ thelin, binding data. Life Sci 51: $1869-1876$

White FJ, Wang RY (1983a): Comparison of the effects of chronic haloperidol treatment on A9 and A10 dopamine neurons in the rat. Life Sci 32:983-993

White FJ, Wang RY (1983b): Differential effects of classical and atypical antipsychotic drugs on A9 and A10 dopamine neurons. Science 221: 1054-1057

White FJ, Wang RY (1984): Pharmacological characterization of dopamine autoreceptors in the rat ventral tegmental area: Microiontophoretic studies. J Pharmacol Exp Ther $231: 275-28()$ 